\title{
Antipsychotics Induced Sexual Dysfunction
}

\section{Judith John*, Rajeev P Thomas, Stephy Paul, Jasmina EK and Kezia Job}

Department of Pharmacy Practice, National College of Pharmacy, Manassery, Kozhikode, Kerala, India

\begin{abstract}
Sexual dysfunction (SD) can be caused by a wide variety of physiological and environmental factors. Antipsychotics induced SD is more prevalent in the modern world. Even though the incidence of antipsychotic induced SD is higher, it is considered as an underreported side effect. Proper management should be done to reduce the impact of antipsychotic induced SD.
\end{abstract}

Keywords: Antipsychotics; Sexual dysfunction

\section{Introduction}

Antipsychotic drugs are highly effective in the treatment of acute psychotic episodes and it equally have the risk of suffering from some of troubling adverse effect [1]. Sexual dysfunction is very common among the patients taking antipsychotic drugs, with a reported prevalence of $45-80 \%$ in males and $30-80 \%$ in females [2]. Sexual dysfunction (SD) can be defined as any reduction in desire or libido, diminished arousal, a decline in the frequency of intercourse, or an undesirable inability to achieve orgasm [3]. In the study by Kotin and co-workers, about $49 \%$ of patients under antipsychotic treatment show sexual dysfunction [4]. And a study by Marrit using structured interviews and self-reported questionnaires have shown that about $16 \%$ to $60 \%$ of the patients using antipsychotics experience sexual dysfunctions [5].

SD due to antipsychotics can be listed as decreased sexual desire, erectile dysfunction, an orgasm, and delayed or retrograde ejaculation. Various sexual side effects caused by different antipsychotics are listed in Table 1. Although the incidence of antipsychotic induced sexual side effects are increasing, only a limited number of researches are done in this area to measure the impact of side effects. Different kind of reasons have been proposed for this lack of attention like underreporting by patients due to embarrassment, a general lack of interest by the treating clinicians to ask about sexual topics, and some doctors consider that asking patients about sexual side effects from their drugs may cause non-compliance [6]. Risperidone and Olanzapine have shown highest sexual dysfunction rates [7].

\begin{tabular}{|c|c|c|}
\hline $\begin{array}{c}\text { Antipsychotic } \\
\text { Drugs }\end{array}$ & $\begin{array}{c}\text { Sexual side effects in } \\
\text { Men }\end{array}$ & $\begin{array}{c}\text { Sexual side effects in } \\
\text { women }\end{array}$ \\
\hline Risperidone & $\begin{array}{c}\text { Erectile or ejaculatory dysfunction } \\
\text { Azoospermia } \\
\text { Gynaecomastia }\end{array}$ & $\begin{array}{c}\text { Infertility } \\
\text { Decreased libido }\end{array}$ \\
\hline Olanzapine & $\begin{array}{c}\text { Reduced libido } \\
\text { Erectile or ejaculatory } \\
\text { dysfunction }\end{array}$ & $\begin{array}{c}\text { Reduced libido } \\
\text { Decreased } \\
\text { lubrication }\end{array}$ \\
\hline Haloperidol & $\begin{array}{c}\text { Gynaecomastia } \\
\text { Reduced libido }\end{array}$ & Amenorrhea \\
\hline Clozapine & $\begin{array}{c}\text { Decreased libido } \\
\text { Erectile dysfunction } \\
\text { Ejaculatory disorder }\end{array}$ & $\begin{array}{l}\text { Decreased libido } \\
\text { Arousal disorder }\end{array}$ \\
\hline Quetiapine & $\begin{array}{c}\text { Gynaecomastia } \\
\text { Decreased libido }\end{array}$ & $\begin{array}{c}\text { Decreased libido } \\
\text { Impaired arousal }\end{array}$ \\
\hline Arpiprazole & $\begin{array}{c}\text { Decreased libido } \\
\text { Impaired arousal }\end{array}$ & $\begin{array}{l}\text { Decreased libido } \\
\text { Impaired arousal }\end{array}$ \\
\hline
\end{tabular}

Table 1: Sexual side effect of both typical and atypical antipsychotic drugs.

\section{Mechanism Involved in the Sexual Dysfunction}

Studies suggest that the prevalence of sexual dysfunction is associated with elevation of prolactin levels [8]. In a six week study, Knegtring et al. found that about $40 \%$ of emerging sexual side effects psychotic disorder mainly in schizophrenia was attributable to the prolactin rising properties of antipsychotics [9]. Antipsychotics are mainly dopamine blockers. Blockade of dopamine receptors by antipsychotics in the tuberoinfundibular tract releases the inhibition of prolactin storage cells, resulting in elevation of prolactin levels [10]. Elevated serum prolactin levels have been shown to have profound effects on reproductive health and sexual function, including hypogonadism, decreased libido in sexes, amenorrhea and infertility in women and low sperm count and reduced muscle mass in men [11].

\section{Assessment of Sexual Dysfunction}

The Global Impression of Sexual Function (GISF) is a self-rated scale by patient that measures an individual's feelings towards his or her sexual function. The GISF is designed to assess sexual desire, arousal (as characterized by penile erection or vaginal lubrication), orgasm, and overall sexual function. Each item was rated from 1 ("normal") to 5 ("severely impaired"). The Changes in Sexual Functioning Questionnaire (CSFQ) is a clinician-rated, structured questionnaire designed to measure dysfunction and changes in sexual function during treatment with medication. The CSFQ, which consists of 36 questions for men and 35 questions for women, assesses components of sexuality pertaining to pleasure, desire/frequency, desire/interest, arousal, and orgasm [12].

\section{Methods to Manage Sexual Dysfunction in Patients taking Antipsychotics}

Physicians should aware of routinely asking about undesired treatment effects of antipsychotics including effects on sexual function, as these drugs have the potential to cause various kinds of abnormalities. In clinical consultation, psychological, social, symptom, and drug-related

*Corresponding author: Judith John, Department of Pharmacy Practice, National College of pharmacy, Manassery, Kozhikode, Kerala 673602, India, Tel: 9745618669; E-mail: judyjohnparapilly@gmail.com

Received July 17, 2017; Accepted November 27, 2017; Published December 08, 2017

Citation: John J, Thomas RP, Paul S, Jasmina EK, Job K (2018) Antipsychotics Induced Sexual Dysfunction. J Psychiatry 21: 433 doi:10.4172/2378-5756.1000433

Copyright: ( 2018 John J, et al. This is an open-access article distributed under the terms of the Creative Commons Attribution License, which permits unrestricted use, distribution, and reproduction in any medium, provided the original author and source are credited 
aspects of sexual performance should be clarified. Also, it is important to try to understand the influence of sexuality on the individual's overall quality of life, in order to assess the need for adjusting treatment. Proper knowledge about the different pharmacological properties of antipsychotics which have effect on sexual performance may be helpful in choosing antipsychotic with a low risk of inducing sexual side effects [13]. Proper follow up is required as there is a chance of reduction in patient compliance to prescribed antipsychotics, when they identify the sexual dysfunction. And if any kind of sexual abnormalities are observed, proper management should be done such as reducing dose of drug or providing appropriate hormone replacement therapy for men and women [14].

\section{Conclusion}

Sexual side effects due to antipsychotics are now considered as under reported side effect all over the world. Even though incidence rates of SD are higher only few are reported due to various reasons. But avoiding antipsychotics is not an applicable method to reduce SD because antipsychotics have a huge beneficial treatment role in psychiatric patients. So the impact of SD due to antipsychotic therapy can be reduced by routine monitoring of patients taking antipsychotics. Successful management of sexual side effects is very crucial for treatment adherence to antipsychotics. And along with this rigorous researches and clinical trials are needed to understand the exact incidence, severity and mechanisms involved in the development of SD induced by various antipsychotic treatment regimens.

\section{References}

1. Bains S, Shah A (2012) Sexual side effects of antipsychotic drugs. Adv Pharmacoepidemiology and Drug Safety 1: 109.

2. Yeon W, Yooseok K, Jun H (2012) Antipsychotic induced sexual dysfunction and its management. World J Mens Health 30: 153-159.
3. Anthony J, Rany S (2013) Psychotropics and sexual dysfunction. Cent European J Urol 66: 466-471.

4. Kotin J, Wilbert D, Verburg D, Soldinger S (2006) Thioridazine and sexual dysfunction. Am J Psychiatry 133: 82-85.

5. Marrit K, Stynke C, Durk W, Robert A, Knegtering H (2015) The facts about sexual (dys)function in schizophrenia: An overview of clinically relevant findings. Schizophr Bull 41: 674-686.

6. Kelly DL, Conley RR (2004) Sexuality and schizophrenia: A review. Schizophr Bull 30: 767-779.

7. La Torre A, Conca A, Duffy D, Giupponi G, Pompili M, et al (2013) Sexual dysfunction related to psychotropic drugs: a critical review part II: antipsychotics. Pharmacopsychiatry 46: 201-208.

8. Hong LS (2009) Sexual dysfunction in patients with schizophrenia treated with conventional antipsychotics or Risperidone. Neuropsychiatric Dis Treat 5: $47-54$.

9. Dickson RA, Glazer WM (1999) Neuroleptic induced hyperprolactinemia. Schizophrenia Res 35: 75-86.

10. Knegtring $\mathrm{H}$, Van den Bosch R, Castelein S, Bruggeman R, Sytema S, et al. (2008) Are sexual side effects of prolactin-rising antipsychotics reducible to serum prolactin? Psychoneuroendocrinology 33: 111-117.

11. Konarzewska B, Szulc A, Poptawska R, Galinska B, Juchnowicz D (2008) Impact of neuroleptic-induced hyperprolactinemia on sexual dysfunction in male schizophrenic patients. Psychiatr Pol 42: 87-95.

12. Kodakandla K, Ajit A, Sandeep G (2014) Validation of sexual functioning questionnaire in Indian patients. Indian J Psychol Med 36: 404-407.

13. Nunes LV, Moreira HC, Razzouk D, Nunes SO, Mari J (2012) Strategies for the treatment of antipsychotic-induced sexual dysfunction and/or hyperprolactinemia among patients of the schizophrenia spectrum: a review. J Sex Marital Ther 38:281-301.

14. Haddad PM, Wieck A (2004) Antipsychotic-induced hyperprolactenemia mechanisms, clinical features and management. Drugs 64: 2291-2314. 